Rev. Asoc. Esp. Neuropsiq. 2020; 40(I 37): 9-I I

DOI: I0.432 I/So2 I I-57352020000 I0000 I

\title{
Sobre salud mental, COVID-19 y normalidad
}

On mental health, COVID-19, and normality

Mikel MunárRiz FerRandis

Psiquiatra. Presidente de la Asociación Española de Neuropsiquiatría-Profesionales de la Salud Mental.

Correspondencia: Mikel Munárriz Ferrandis (munarriz@uji.es)

T a pandemia De COVID-ig nos ha llevado, como profesionales de la salud Lmental, a reorganizar, a toda velocidad, la atención desde nuestros servicios. Sin esperar instrucciones hemos demostrado una notable capacidad para la autogestión y la adaptación a las exigencias de cada lugar y cada momento.

Más que un "mando único" y una "autoridad competente", hemos echado de menos más información y más medios.

Nuestro supuesto saber fue también rápidamente demandado, sobre todo desde los medios de comunicación, para que explicáramos en cualquier telediario el impacto psicológico de la pandemia y los doctos consejos para resistir el confinamiento o soportar el dolor de las pérdidas.

El mismo ritmo galopante se intuye ahora para transitar hacia la ¿̨nueva? normalidad. Como Asociación sentimos la presión para posicionarnos, participar en grupos de trabajo, sacar conclusiones y proponer medidas desde la autoridad "técnica" que se nos atribuye.

$\mathrm{La}$ ONU y la OMS publican informes que son aceleradamente resumidos en titulares de prensa como el vaticinio de un impacto gigantesco sobre la salud mental de la población mundial.

Su lectura más atenta no sostiene esa conclusión. E incluso podrían ser leídos en sentido contrario. ¿No es realmente preocupante que solo entre un 34 a un $45 \%$ de los profesionales sanitarios haya reconocido ansiedad, desesperanza o problemas para dormir? 
Una interpretación más pausada sería que esta pandemia ha resaltado las deficiencias estructurales y funcionales de los sistemas de atención a la salud mental a nivel mundial. Que ya existían antes de que el virus entrara en nuestras comunidades. Como hace seis meses, necesitamos más recursos y también otra manera de ponerlos al servicio de las necesidades de las personas que han de usarlos. La nueva normalidad ha de ser otra normalidad. Que no deje atrás y con un diagnóstico como consuelo a quienes no la alcanzan. La anterior normalidad ya estaba en crisis.

Y así poder acoger también con agilidad y respeto a quienes han atravesado la enfermedad con más dureza o han sufrido pérdidas muy dolorosas.

Se puede entender e incluso apoyar que desde los foros profesionales se usen estas predicciones para reclamar más "de lo mío", de una determinada disciplina o en un determinado ámbito. Pero también incomoda el particularismo.

Ya sabemos, desde hace tiempo, que somos pocos. Y que además esta escasez no se distribuye por igual entre todas las profesiones, ni entre todos los territorios del Estado. Tampoco es el balance adecuado entre los ámbitos hospitalario y comunitario. Y abriendo el foco, compartimos la precariedad con la Atención Primaria y los Servicios Sociales de Base.

Pero también sabíamos, y ahora con más argumentos, que el sufrimiento psíquico está muy unido a la pobreza y a las desigualdades. Atajarlas es la mejor medida para "tratarlo". Se prevendrán más suicidios con una renta básica universal que con legiones de profesionales psicopatologizando cualquier atisbo de desesperanza.

Desigualdad y exclusión van unidas también en otros ejes, como los del género, la raza, la ciudadanía "administrativa" o ser mayor, niña o "grupo de riesgo". Fracturas que la COVID-19 ha resaltado.

Hay que formarse y poner en marcha formas de ayuda desligadas de los diagnósticos y las etiquetas, que prevengan sus efectos iatrogénicos. Las conocemos y las usamos, pero están aún lejos de formar parte de nuestra "caja de herramientas" de cada día.

La cuestión técnica tiene una parte topológica. De lugar y de posición. Espacios más cercanos a la comunidad y que permitan más horizontalidad entre todos los actores.

La prensa británica proponía que el Estado condecorara a los sanitarios como héroes de guerra y que la RAF hiciera volar sus escuadrillas de honores a la hora de los aplausos. Eso, desde luego que no; pero que los profesionales de la salud han de ser bien tratados y dignamente pagados es otra de las lecciones que ya sabíamos desde las mareas blancas. Y, ahora o nunca, es momento de reconocernos como vulnerables y necesitados de apoyo entre nosotras y desde las instituciones en las que trabajamos.

Un reconocimiento que hemos de compartir con las personas con sufrimiento psíquico, cuya sabiduría y capacidad de autoorganización y apoyo mutuo ha de 
incorporarse a la práctica, a la gestión de los servicios, a la formación y la génesis del conocimiento. Todas estamos juntas en esto.

Cada una de estas propuestas puede ser redireccionada para apoyar la vieja normalidad. Enmascaradas en estrategias de humanización, de participación formalista, de "gestión" del malestar emocional, de colaboración "desinteresada" y "socialmente responsable" del sector privado o la caridad organizada, en la fascinación por lo telemático, de la instrumentalización de la evidencia y el saber técnico... Hay que estar alerta.

Por este motivo, cualquier normalidad deseable pasa por el refuerzo del Sistema Nacional de Salud, público, universal, integrado, multiprofesional, participativo. Que no funcione cotidianamente al límite de sus posibilidades y que se sepa cuidar. 